\title{
Involvement of exogenous 3-deoxyglucosone in $\beta$-cell dysfunction induces impaired glucose regulation
}

\author{
LURONG ZHANG ${ }^{*}$, LIANG ZHOU* ${ }^{*}$ XIUDAO SONG, GUOQIANG LIANG, \\ ZHONGRUI XU, FEI WANG, FEI HUANG and GUORONG JIANG
}

\begin{abstract}
Suzhou Academy of Wumen Chinese Medicine, Suzhou Hospital of Traditional Chinese Medicine, Nanjing University of Chinese Medicine, Suzhou, Jiangsu 215003, P.R. China
\end{abstract}

Received August 2, 2016; Accepted May 4, 2017

DOI: $10.3892 / \mathrm{mmr} .2017 .6856$

\begin{abstract}
. $\beta$-cell dysfunction is the primary cause of type 2 diabetes mellitus (T2DM). 1,2-dicarbonyl compounds, such as 3-deoxyglucosone (3DG) have been reported to increase the risk of T2DM. Abnormal elevation of plasma 3DG may impair $\beta$-cell function and thereby, it is linked to T2DM. Previous findings suggest that exogenous 3DG may serve an important role in the development of pre-diabetes. In the present study, the authors examine whether exogenous 3DG induces impaired glucose regulation in mice by decreasing $\beta$-cell function involving of accumulation of plasma 3DG. At two weeks following administration of 3DG, fasting blood glucose (FBG) levels, oral glucose tolerance (by a glucose meter) and plasma levels of 3DG (by HPLC) and insulin (by radioimmunoassay) were measured. Glucose-stimulated insulin secretion in cultured pancreas islets and INS-1 cells was measured by radioimmunoassay. Western blotting was used to examine the expression of the key molecules of the insulin-PI3K signaling pathway. 3DG treatment increased FBG and fasting blood insulin levels, reduced oral glucose tolerance in conjunction with decreased $\Delta \mathrm{Ins}_{30-0} / \Delta \mathrm{G}_{30-0}$. In 3DG-treated mice, an increase in the plasma 3DG level was observed, which was most likely the mechanism for decreased $\beta$-cell function. This idea was further supported by these results that non-cytotoxic 3DG concentration obviously decreased glucose-stimulated insulin secretion in cultured pancreas islets and INS-1 cells exposure to high glucose $(25.5 \mathrm{mM})$. 3DG decreased the expression of GLUT2 and phosphorylation of IRS-1, PI3K-p85 and Akt in high glucose-induced INS-1 cells. To the best of the authors' knowledge, the present study is the first to demonstrate
\end{abstract}

Correspondence to: Dr Guorong Jiang, Suzhou Academy of Wumen Chinese Medicine, Suzhou Hospital of Traditional Chinese Medicine, Nanjing University of Chinese Medicine, 18 Yangsu Road, Suzhou, Jiangsu 215003, P.R. China

E-mail: guorongjiang@hotmail.com

${ }^{*}$ Contributed equally

Key words: 3-deoxyglucosone, $\beta$-cell dysfunction, impaired glucose regulation, insulin signaling that exogenous 3DG induced normal mice to develop IGR, resulting from $\beta$-cell dysfunction. Exogenous 3DG administration increased plasma 3DG levels, which participates in inducing $\beta$-cell dysfunction, at least in part, through impairing IRS-1/PI3K/GLUT2 signaling.

\section{Introduction}

Pre-diabetes, referring to impaired fasting glucose and/or impaired glucose tolerance, manifest both core pathophysiological features of type 2 diabetes mellitus (T2DM), that is, insulin resistance and $\beta$-cell dysfunction $(1,2)$. Several key insulin target tissues including muscle, fat and liver become resistant to the actions of insulin in the progression to pre-diabetes. Accumulated data have identified that pancreatic $\beta$-cells are also targets of insulin action (3). Indeed, the insulin signal transduction pathway in $\beta$-cells serves a crucial role in regulating the synthesis, secretion of insulin and maintaining the growth, proliferation and survival of cells (4). Furthermore, tissue-specific knockout of the insulin receptor (IR), insulin receptor substrate (IRS)-1 or IRS-2 in $\beta$-cells both display defects in insulin secretory responses to glucose stimuli (5-8). Considering the significant role of insulin on $\beta$-cells, insulin resistance is also thought to affect the functioning of $\beta$-cells in addition to that of the muscle, fat and liver tissues. Therefore, defects in insulin signaling in $\beta$-cells appear to be implicated in the pathogenesis of pre-diabetes. Phosphoinositide 3-kinase (PI3K) is proposed to be a key signaling molecule in insulin signaling. Insulin binds to the IR of $\beta$-cells, triggering receptor auto-phosphorylation, receptor tyrosine kinase activation, IRS-1 phosphorylation and PI3K activation (9). The insulin-PI3 K signaling pathway has been demonstrated to be involved in regulating insulin secretion and insulin gene transcription $(10,11)$.

1,2-dicarbonyl compounds, such as methylglyoxal (MGO) and 3-deoxyglucosone (3DG), which are easily formed from carbohydrates in caramelization and Maillard reactions in food, have been reported to increase the risk of T2DM and its complications $(12,13)$. Indeed, MGO was also reported to induce insulin resistance in cultured L6 muscle cells (14) and 3T3-L1 adipocytes (15) through impairing insulin signaling pathways. Incubation of cultured INS-1 $\beta$-cells with MGO also impairs insulin signaling and insulin action on glucose-induced 
insulin secretion (16). Despite advances in understanding of the pathogenesis linking MGO with T2DM, MGO has been reported to be less toxic than $3 \mathrm{DG}$ in embryonic malformation (17). Furthermore, dietary intake of 3DG was estimated to be range from 20 to $160 \mathrm{mg} / \mathrm{day}$, which is higher than that of MGO in the range of 5-20 mg/day, thus 3DG was proved to be the predominant 1,2-dicarbonyl compound (18). Importantly, although 3DG has been reported to exert deleterious effects on many aspects similar to MGO (19-22), the previous findings surprisingly presented that $\mathrm{MGO}$ and 3DG modulated collagen expression differently (23). Such observations are the important cause, which suggests that the role of 3DG on the development of T2DM deserves to be further investigated. Previously, exogenous 3DG was administrated to normal mice for two weeks and led to a significant increase in blood glucose concentration at 30 min during an oral glucose tolerance test (OGTT) (24). These findings strongly suggest that exogenous 3DG may serve an important role in development of pre-diabetes.

It has reported that the level of plasma 3DG was elevated $\sim$ two-fold in patients with diabetes, compared with healthy humans (25-27). Previous studies of the authors indicated that there was an abnormal elevation of plasma 3DG in non-diabetic seniors, and the increasing accumulation of plasma 3DG may eventually leads to impaired glucose regulation (IGR) through decreasing insulin sensitivity and reducing insulin secretion (28). These findings suggest that accumulation of endogenous 3DG may serve an important role in the development of diabetes. This idea is further supported by the previous finding that acute administrated 3DG to normal rats to achieve the pathologically relevant plasma levels of 3DG that induced glucose intolerance through impairing the insulin-PI3K signaling pathway involving insulin resistance and impaired $\beta$-cell function (29). In addition, the authors indicated that 3DG induced insulin resistance in hepatocellular carcinoma cells HepG2 through impairing the insulin-PI3 K signaling pathway and insulin action on glucose uptake and glycogen synthesis (30). These results are sufficient to indicate that abnormal elevation of circulating 3DG may participate in worsening of diabetic state and the development of diabetes, associated with the impairment of insulin action on target tissues. Importantly, $\beta$-cells maintain normal glucose tolerance by increasing insulin output in the present of insulin resistance, and only when $\beta$-cells are incapable of releasing sufficient insulin do glucose concentrations rise (31). This islet-centered view is also reflected by current diabetes treatment options (32). Finally, the dominant thought was that $\beta$-cell dysfunction was the main pathogenesis of T2DM. Therefore, $\beta$-cell dysfunction is believed to involve in the deleterious effects of exogenous 3DG on blood glucose concentrations. In this case, the link between exogenous 3DG and $\beta$-cell dysfunction may be increased plasma levels of 3DG, which remains to be clarified. The aim of the present work was to investigate whether continuous oral administration of 3DG leads to normal individuals developing IGR, resulting from $\beta$-cell dysfunction induced by an increase in plasma 3DG levels.

In the present study, 3DG was administered by gastric gavage to normal mice for two weeks to examine the plasma 3DG levels. The effects of intragastric administration of 3DG on the fasting blood glucose and oral glucose tolerance were investigated. In addition, the effect of 3DG on $\beta$-cell function in mice was assessed by calculating homeostasis model assessment (HOMA)- $\beta$ and $\Delta \mathrm{Ins}_{30-0} / \Delta \mathrm{G}_{30-0}$ and in cultured pancreas islets and INS-1 cells by measuring glucose-stimulated insulin secretion (GSIS). Furthermore, the authors investigated the ability of 3DG to interfere with insulin-PI3K signaling in glucose-induced INS-1 cells.

\section{Materials and methods}

Synthesis of 3DG. According to the method of Kato et al (33), $3 \mathrm{DG}$ was synthesized from glucose as previously described (30).

Determination of appropriate doses of intragastric administration of $3 D G$. Previous reports have estimated an average dietary 3DG intake of about $50 \mathrm{mg} / \mathrm{day}$, based on the 3DG content in commonly consumed foods (18). In order to achieve the equivocal effect of a potential 3DG intake of $50 \mathrm{mg} / \mathrm{day}$, the authors calculated doses based on body surface area $(6.5 \mathrm{mg} / \mathrm{kg}$ for mice and $4.5 \mathrm{mg} / \mathrm{kg}$ for rats). Previously, it was reported that intragastric administration of $5 \mathrm{mg} / \mathrm{kg} 3 \mathrm{DG}$ for two weeks increased blood glucose level under oral glucose tolerance tests in mice (24). Therefore, the present study involved administration of 5, 20 and $50 \mathrm{mg} / \mathrm{kg}$ 3DG by gastric gavage.

Animals. Male Kunming mice (6-8-weeks-old) and male Sprague-Dawley rats (11-weeks-old) were purchased from Joinn Laboratories Co., Ltd. (Suzhou, Jiangsu, China) and housed in a temperature-controlled room $\left(23^{\circ} \mathrm{C}\right)$ and $12-\mathrm{h}$ light/dark cycle. All of animal experimental procedures were conducted in compliance with Guide for Care and Use of Laboratory Animals of the National Institutes of Health (Bethesda, MD, USA). The study was approved by the local ethic committee of Suzhou Hospital of Traditional Chinese Medicine (Suzhou, Jiangsu, China). The mice and rats had free access to a standard diet (Shuangshi Laboratory Animal Feed Science Co., Ltd., Suzhou, Jiangsu, China) and water. The mice were randomly distributed into four groups and each group consisted of six mice. They were treated with water (control group), $5 \mathrm{mg} / \mathrm{kg} 3 \mathrm{DG}, 20 \mathrm{mg} / \mathrm{kg} 3 \mathrm{DG}$ and $50 \mathrm{mg} / \mathrm{kg}$ 3DG by gastric gavage at 9:00 am every day for two weeks. Following two weeks, the mice were fasted overnight and killed following completion of an OGTT. In a second study, following overnight fasting, the rats were anaesthetized with pentobarbital sodium $(50 \mathrm{mg} / \mathrm{kg})$ and given intravenous injection of $3 \mathrm{DG}(5,20$ and $50 \mathrm{mg} / \mathrm{kg})$. At $2 \mathrm{~h}$, pancreas islet tissues were isolated and subsequently cultured for the measurement GSIS.

OGTT. The mice were fasted overnight, and then intragastric administration of $2.5 \mathrm{~g} / \mathrm{kg}$ glucose was performed following measurement of the fasting blood glucose and fasting insulin levels. The blood glucose was detected at 30,60 and $120 \mathrm{~min}$, and the insulin level was detected at 30 min following the glucose load. The blood samples were obtained from caudal vein and a glucose meter determined blood glucose. Blood samples were obtained by enucleating the eyeballs and insulin concentration was determined using an insulin radioimmunoassay kit 
(Beijing North Institute of Biological Technology, Beijing, China). The blood glucose concentration-time curves were plotted and the area under curve (AUC) was calculated for each group. The $\beta$-cell function was assessed by HOMA- $\beta$ and $\Delta \mathrm{Ins}_{30-0} / \Delta \mathrm{G}_{30-0}$. All indexes were calculated using the following formulas: AUC mmol.h/l=1/2A+B+C+1/2D (A, B, C, D indicated the blood glucose of $0,30,60$ and 120 min respectively, mM), HOMA- $\beta=20 x F I N S /($ FBG-3.5), $\Delta \mathrm{Ins}_{30-0} / \Delta \mathrm{G}_{30-0}=\left(\mathrm{Ins}_{30}-\mathrm{Ins}_{0}\right) /\left(\mathrm{G}_{30}-\mathrm{G}_{0}\right)(\mathrm{FBG}$, fasting blood glucose, mM; FINS, fasting insulin, mIU/l).

INS-1 cell culture and GSIS study. INS-1 cells were kindly provided by School of Biology and Basic Medical Sciences of Soochow University (Suzhou, Jiangsu, China). The islets and INS-1 cells were cultured in phenol-red free RPMI medium (Gibco; Thermo Fisher Scientific, Inc., Waltham, MA, USA) containing $11 \mathrm{mM}$ glucose, $10 \%$ charcoal stripped fetal bovine serum, $1 \mathrm{mM}$ glutamine, $100 \mathrm{U} / \mathrm{ml}$ penicillin and $100 \mathrm{mg} / \mathrm{ml}$ streptomycin. For GSIS experiment, the cells were plated at a density of $4 \times 10^{3}$ per well in a 96-well plate overnight and then treated with and without different concentrations of 3DG $(0$, 80,300 and $500 \mathrm{ng} / \mathrm{ml}$ ) in RPMI1640 containing different glucose content (5.6 or $25.5 \mathrm{mM}$ ). Following incubation for $12 \mathrm{~h}$ at $37^{\circ} \mathrm{C}$ in a humidified incubator, the culture solution was collected and MTT $(5 \mathrm{mg} / \mathrm{ml}$ in PBS) was added to each well and incubated for $4 \mathrm{~h}$, then the medium was totally removed. Finally, $0.1 \mathrm{ml}$ buffered dimethyl sulfoxide (Wuxi Zhanwang Chemical Reagent Co., Ltd., Wuxi, Jiangsu, China) was added to each well. The absorbance was recorded on a microplate reader (Spectra Max M2e, Molecular Devices, LLC, Sunnyvale, CA, USA) at the wavelength of $490 \mathrm{~nm}$. The insulin of the culture solution was detected by radioimmunoassay.

GSIS study of pancreas islets. The rats were anaesthetized with pentobarbital sodium $(50 \mathrm{mg} / \mathrm{kg})$ and pancreas islet tissues were isolated. These tissues subsequently were chopped and digested by collagenase $(1.5 \mathrm{mg} / \mathrm{ml}$ in RPMI1640) for $20 \mathrm{~min}$ at $37^{\circ} \mathrm{C}$ for the measurement GSIS. Briefly, the digested pancreases were filtered and centrifuged at $3,000 \mathrm{xg}$ at $4^{\circ} \mathrm{C}$. The supernatant was discarded, and the pellet was resuspended in the RPMI1640. The islet cells were plated at a density of $4 \times 10^{3}$ per well in 96-well plates overnight and then treated with different concentrations of 3DG $(0,80,300$ and $500 \mathrm{ng} / \mathrm{ml}$ ) in RPMI1640 containing different glucose content $\left(5.6\right.$ or $25.5 \mathrm{mM}$ ). Following incubation for $12 \mathrm{~h}$ at $37^{\circ} \mathrm{C}$ in a humidified incubator, the insulin of the culture solution was detected by radioimmunoassay. In another study, the rats were anaesthetized with pentobarbital sodium $(50 \mathrm{mg} / \mathrm{kg})$ and given an intravenous injection of 3DG $(5,20$ and $50 \mathrm{mg} / \mathrm{kg})$. At $2 \mathrm{~h}$, pancreas islet tissues were isolated and subsequently cultured for the measurement GSIS, as described previously (29). The insulin of the culture solution was detected by radioimmunoassay.

Plasma 3DG measurement. At two weeks following intragastric administration of 3DG, the mice were sacrificed and blood sample was obtained from enucleating the eyeballs for the measurement of 3DG contents by high performance liquid chromatography, as described previously (29).
Western blot analysis. INS-1 cells were grown to confluence in six-well culture dishes and incubated with different concentrations of 3DG $(0,80,300$ and $500 \mathrm{ng} / \mathrm{ml})$ for $12 \mathrm{~h}$ under high glucose condition $(25.5 \mathrm{mM})$. After $12 \mathrm{~h}$ of treatment, the cells were harvested and solubilized in IP lysine buffer containing $20 \mathrm{mM}$ Tris (pH 7.5), $150 \mathrm{mM} \mathrm{NaCl}, 1 \%$ Triton X-100, 2 mM SDS, $25 \mathrm{mM} \beta$-glycerophosphate, 1 mM EDTA, $1 \mathrm{mM} \mathrm{Na} 3 \mathrm{VO} 4$ and $0.5 \mu \mathrm{g} / \mathrm{ml}$ leupeptin (Beyotime Institute of Biotechnology, Nantong, Jiangsu, China). Following centrifugation at $12,000 \times \mathrm{g}$ at $4^{\circ} \mathrm{C}$ for $20 \mathrm{~min}$, the supernatants were collected and used for Western blot analysis. The total protein concentrations were determined using a bicinchoninic acid protein (BCA) assay kit (cat. no. P0012; Beyotime Institute of Biotechnology) comprising BCA kit A (cat. no. P0012-1), BCA kit B (cat. no. P0012-2) and standard proteins (cat. no. P0012-3). The proteins $(100 \mu \mathrm{g})$ were loaded onto a 12\% SDS-polyacrylamide gel (Thermo Fisher Scientific, Inc.), then subjected to electrophoresis and transferred onto polyvinylidene fluoride membranes (Merck KGaA, Darmstadt, Germany). The membranes were blocked for $1 \mathrm{~h}$ in Tris-buffered saline with $1 \%$ Tween (TBST; Beijing Solarbio Science \& Technology Co., Ltd., Beijing, China) containing 5\% dry milk. The membranes were washed with phosphate-buffered saline (PBS; Beyotime Institute of Biotechnology) containing 0.05\% Tween-20 3 times, and incubated at $4^{\circ} \mathrm{C}$ overnight with the following antibodies: rabbit polyclonal anti-insulin receptor substrate 1 (IRS-1; cat. no. 2390), rabbit polyclonal anti-phospho-IRS-1 (IRS-1; cat. no. 3070), rabbit polyclonal anti-phosphoinositide 3-kinase (PI3K)-p85 (cat. no. 4292), rabbit polyclonal anti-Akt (cat. no. 9272) and rabbit polyclonal anti-phospho-Akt (Ser473; cat. no. 9271), all purchased from Cell Signaling Technology, Inc. (Danvers, MA, USA; dilution, 1:1,000 each), and rabbit polyclonal anti-glucose transporter 2 (GLUT2; cat. no. ab54460), purchased from Abcam (Cambridge, UK; 1:500). Following washing 4 times for 5 min each in TBST, the membranes were incubated with goat anti-rabbit secondary antibody [1:1,000; cat. no. GAR0072; Multi Sciences (Lianke) Biotech Co., Ltd., Hangzhou, China] for $2 \mathrm{~h}$ and visualized using an ECL detection kit (cat. no. PE0010; Beijing Solarbio Science \& Technology Co., Ltd.). Quantification of protein bands was performed using ImageJ software version 1.42 (National Institutes of Health, Bethesda, MD, USA).

Statistical analysis. Results of the experimental studies are expressed as mean \pm standard deviation. Statistical significance of differences was analyzed by the Student's t-test or one-way analysis of variance. $\mathrm{P}<0.05$ was considered to indicate a statistically significant difference.

\section{Results}

The effects of intragastric administration of $3 D G$ for two weeks on plasma 3DG levels, fasting blood glucose and oral glucose tolerance in mice. Given the evidence for the role of circulating 3DG in the development of pre-diabetes, the author firstly investigated whether continuous oral administration of 3DG increased plasma levels of 3DG. At two weeks following administration, the plasma level of 3DG was significantly increased in 3DG-treated mice compared 

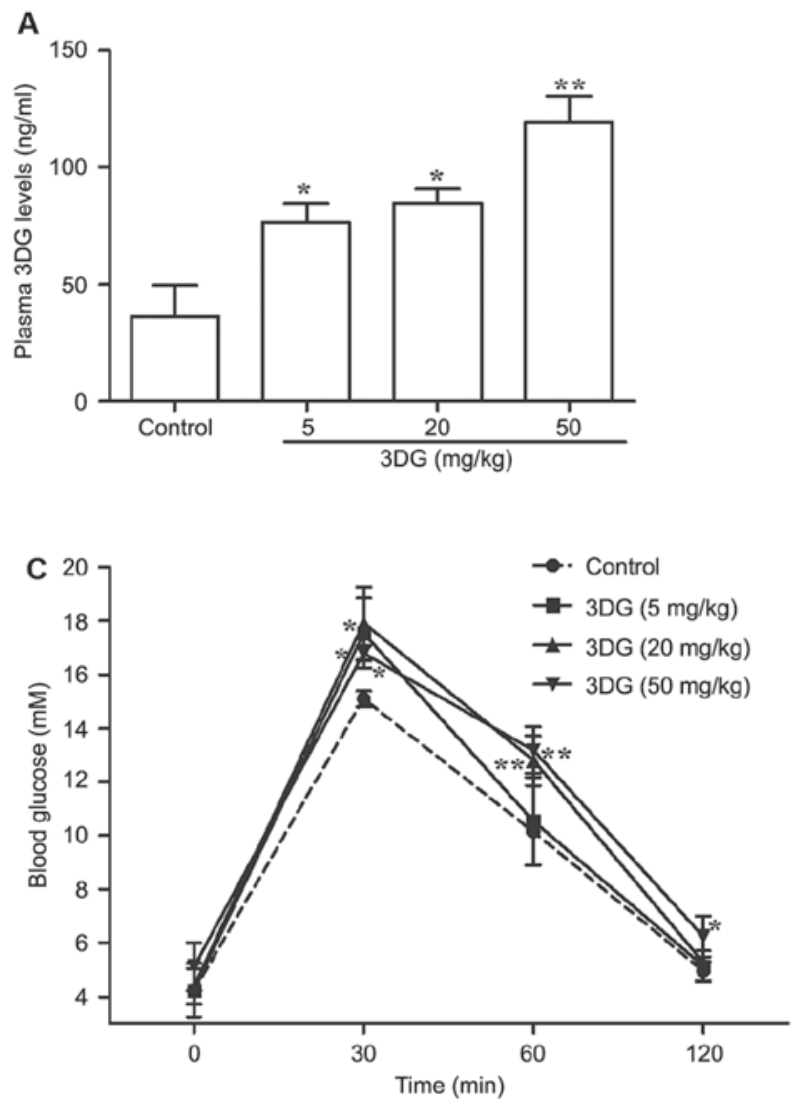
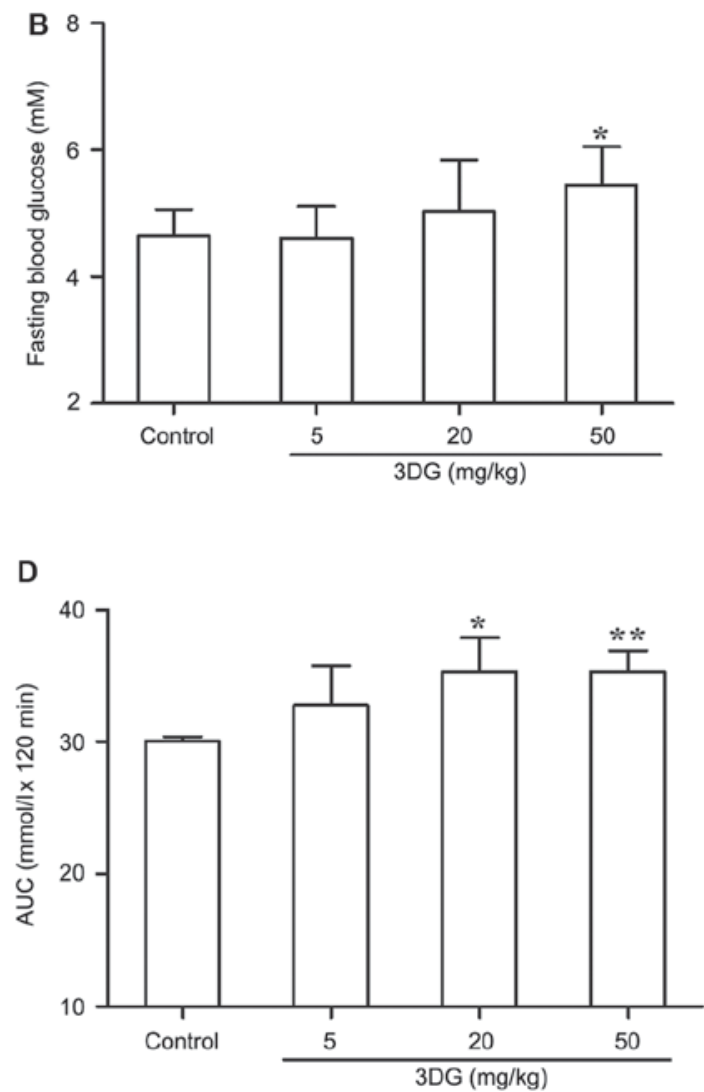

Figure 1. The effects of intragastric administration of 3DG for two weeks on plasma 3DG levels, fasting blood glucose and oral glucose tolerance in mice. (A) The plasma 3DG concentrations were measured by high performance liquid chromatography in mice two weeks following intragastric administration of 3DG $(5,20$ and $50 \mathrm{mg} / \mathrm{kg})$. (B) Fasting blood glucose levels were measured by a glucose meter in mice two weeks following intragastric administration of $3 \mathrm{DG}(5,20$ and $50 \mathrm{mg} / \mathrm{kg})$. (C) The blood glucose concentration-time curves were measured after intragastric administration of glucose (2.5 g/kg) in mice treated with $3 \mathrm{DG}(5,20$ and $50 \mathrm{mg} / \mathrm{kg}$ ) for two weeks. (D) The AUCs were calculated of the blood glucose concentration-time curves using the following formulas: AUC mmol.h/l=1/2A+B+C+1/2D (A, B, C and D was the blood glucose at 0, 30, 60 and 120 min, respectively, mM). Values are presented as the mean \pm standard deviation. ${ }^{*} \mathrm{P}<0.05,{ }^{* *} \mathrm{P}<0.01$ vs. control $(\mathrm{n}=6)$. AUC, area under the curve; 3DG, 3-deoxyglucosone.

with the control (control, 36.22 $\pm 13.51 \mathrm{ng} / \mathrm{ml} ; 5 \mathrm{mg} / \mathrm{kg} 3 \mathrm{DG}$, $76.67 \pm 7.98 \mathrm{ng} / \mathrm{ml} ; \mathrm{P}<0.05 ; 20 \mathrm{mg} / \mathrm{kg} 3 \mathrm{DG}, 84.75 \pm 6.04 \mathrm{ng} / \mathrm{ml}$; $\mathrm{P}<0.05 ; 50 \mathrm{mg} / \mathrm{kg} 3 \mathrm{DG}, 119.58 \pm 10.67 \mathrm{ng} / \mathrm{ml} ; \mathrm{P}<0.01$; Fig. 1A). Then, fasting blood glucose was measure in another two week 3DG administration experiment. The fasting blood glucose levels of $50 \mathrm{mg} / \mathrm{kg}$ 3DG-treated mice were higher than that of control mice $(50 \mathrm{mg} / \mathrm{kg} 3 \mathrm{DG}$ vs. control, $5.45 \pm 0.603 \mathrm{mM}$ vs. $4.644 \pm 0.413 \mathrm{mM}$; P<0.05; Fig. 1B). 3DG-treated mice had impaired oral glucose tolerance in dose-dependent manner compared with control mice (Fig. 1C; $5 \mathrm{mg} / \mathrm{kg} 3 \mathrm{DG}$ vs. control, at $30 \mathrm{~min}, \mathrm{P}<0.05 ; 20 \mathrm{mg} / \mathrm{kg} 3 \mathrm{DG}$ vs. control, at 30 and $60 \mathrm{~min}, \mathrm{P}<0.05$ and $\mathrm{P}<0.01 ; 50 \mathrm{mg} / \mathrm{kg} 3 \mathrm{DG}$ vs. control, at $30,60,90 \mathrm{~min}, \mathrm{P}<0.05, \mathrm{P}<0.01, \mathrm{P}<0.05$, respectively). The AUC of OGTT results also demonstrated that the difference between 3DG-treated group with either $20 \mathrm{mg} / \mathrm{kg}$ dose or $50 \mathrm{mg} / \mathrm{kg}$ does and control group was statistically significant (Fig. 1D; $20 \mathrm{mg} / \mathrm{kg}$ 3DG vs. control, $\mathrm{P}<0.05 ; 50 \mathrm{mg} / \mathrm{kg} 3 \mathrm{DG}$ vs. control, $\mathrm{P}<0.01)$. These results indicated the increased level of 3DG in the plasma may be responsible for the 3DG-induced IGR in mice.

The effects of intragastric administration of $3 D G$ for two weeks on plasma insulin and the insulin secretion index in mice. In consideration of the importance of $\beta$-cell dysfunction to the pathogenesis of pre-diabetes, the authors evaluated the potential damaging impact of exogenous 3DG on $\beta$-cell function (Fig. 2). Under fasting conditions, there was a noticeable increase in plasma insulin levels between the control group $(14.396 \pm 3.505 \mathrm{mIU} / \mathrm{l})$ and 3DG-treated groups $(20 \mathrm{mg} / \mathrm{kg} 3 \mathrm{DG}, 19.015 \pm 0.891 \mathrm{mIU} / 1, \mathrm{P}<0.05$; $50 \mathrm{mg} / \mathrm{kg} 3 \mathrm{DG}, 21.465 \pm 3.618 \mathrm{mIU} / 1, \mathrm{P}<0.05$; Fig. 2A). Whereas no significant difference in insulin plasma levels was observed between 3DG-treated groups and control group $30 \mathrm{~min}$ following the glucose load (Fig. 2B). In addition, compared with the control group, 3DG-treated mice with either $20 \mathrm{mg} / \mathrm{kg}$ dose or $50 \mathrm{mg} / \mathrm{kg}$ doses exhibited a significant reduction of $\Delta \mathrm{Ins}_{30-0} / \Delta \mathrm{G}_{30-0}$ (the early phase of insulin secretion) (Fig. 2D, $20 \mathrm{mg} / \mathrm{kg} 3 \mathrm{DG}$ vs. control, $1.546 \pm 0.231$ vs. $1.081 \pm 0.223, \mathrm{P}<0.05 ; 50 \mathrm{mg} / \mathrm{kg} 3 \mathrm{DG}$ vs control, $1.546 \pm 0.231$ vs. $1.006 \pm 0.201, \mathrm{P}<0.01)$ whereas no difference in HOMA- $\beta$ was detected in 3 DG-treated mice compared with control mice (Fig. 2C). These results indicated that administration of exogenous 3DG could have the ability to affect $\beta$-cell function.

The effect of $3 D G$ treatment on GSIS in cultured islets and INS-1 cells. To further investigate the effect of 3DG on $\beta$-cell function, the GSIS was measured in cultured pancreas islets and INS-1 cells (Fig. 3). Compared with the control group, GSIS in cultured pancreas islets and INS-1 cells treatment 

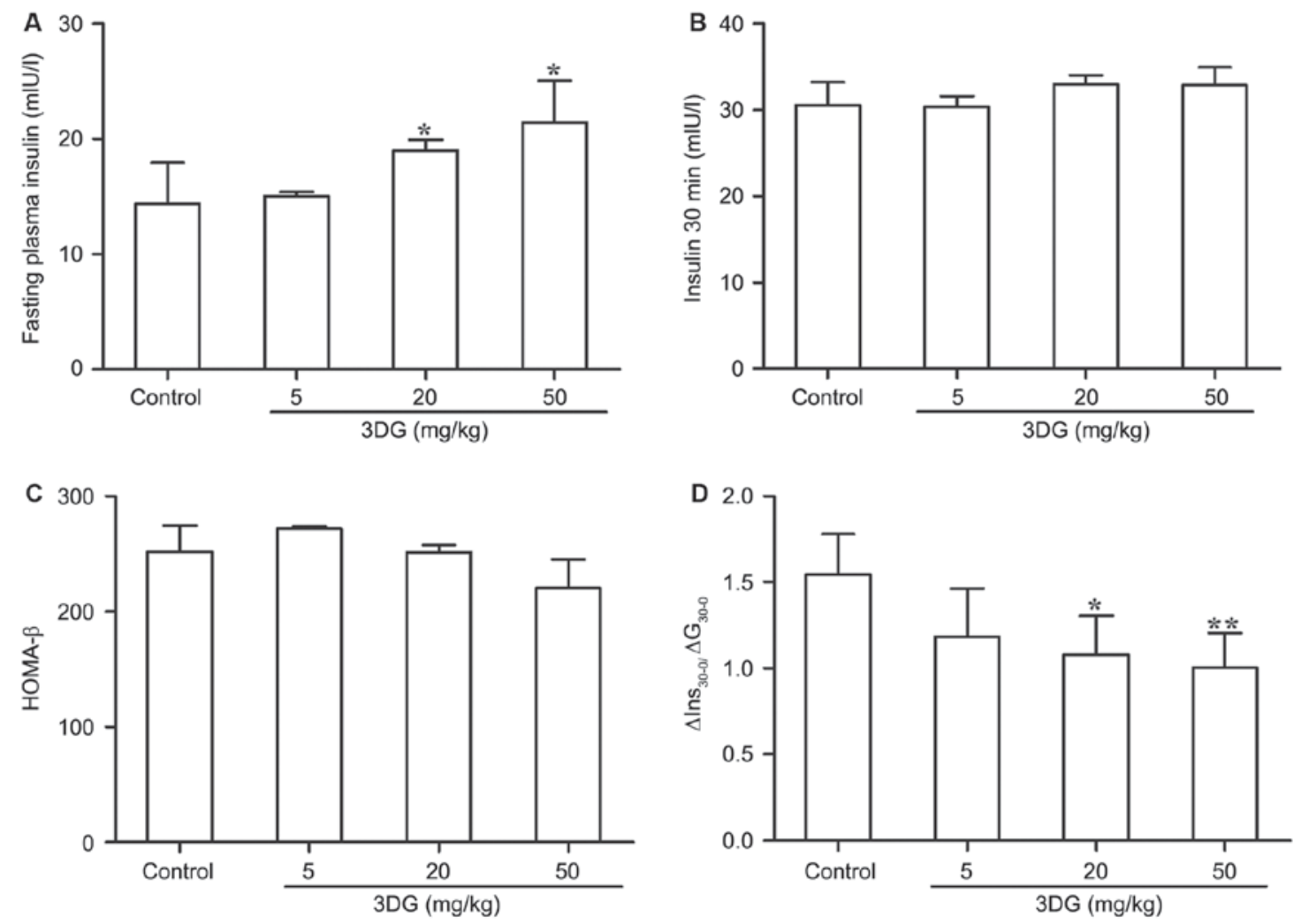

Figure 2. The effects of intragastric administration of 3DG for two weeks on plasma insulin and the insulin secretion index in mice. The insulin levels were measured at (A) 0 and (B) $30 \mathrm{~min}$ in mice treated with 3DG $(5,20$ and $50 \mathrm{mg} / \mathrm{kg})$ for two weeks following intragastric administration of glucose $(2.5 \mathrm{~g} / \mathrm{kg})$. The insulin secretion index [(C) HOMA- $\beta$ and (D) $\left.\Delta \mathrm{Ins}_{30-0} / \Delta \mathrm{G}_{30-0}\right]$ were calculated using the following formulas: HOMA- $\beta=20 x F I N S /(\mathrm{FBG}-3.5)$, $\Delta \mathrm{Ins}_{30-0} / \Delta \mathrm{G}_{30-0}=\left(\mathrm{Ins}_{30^{-}} \mathrm{Ins}_{0}\right) /\left(\mathrm{G}_{30}-\mathrm{G}_{0}\right)$. 3DG, 3-deoxyglucosone; FBG, fasting blood glucose, mM; FINS, fasting insulin, mIU/1. Values are presented as the mean \pm standard deviation. ${ }^{*} \mathrm{P}<0.05,{ }^{* *} \mathrm{P}<0.01$ vs. control $(\mathrm{n}=6)$.

with 3DG was decreased following exposure to high glucose (25.5 mM; Fig. 3A and C). Furthermore, under the conditions tested 3DG at concentrations of 80,300 and $500 \mathrm{ng} / \mathrm{ml}$ failed to alter INS-1 viability. Additionally, as demonstrated in Fig. 3D, high GSIS was lower in cultured pancreas islets from the acute intravenous injection of 3DG-treated rats than that of control rats $(5 \mathrm{mg} / \mathrm{kg} 3 \mathrm{DG}$ vs. control, 0.93 -fold, $\mathrm{P}<0.05$; $20 \mathrm{mg} / \mathrm{kg}$ 3DG vs. control, 0.86-fold, $\mathrm{P}<0.01 ; 50 \mathrm{mg} / \mathrm{kg}$ $3 \mathrm{DG}$ vs. control, 0.79 -fold, $\mathrm{P}<0.01)$. However, there was no significant difference among the different groups under low glucose condition (5.6 mM; Fig. 3B, C and D). Finally, 3DG is demonstrated to exert deleterious effects on insulin secretion under high glucose condition.

The effects of 3DG treatment on insulin signaling in INS-1 cells. The authors further explored a potential mechanism by which 3DG decreased insulin levels in response to a high glucose challenge. Considering the significant role of insulin on $\beta$-cell function, the ability of 3DG to impair insulin signaling in the INS-1 $\beta$-cell line was investigated. Thus, the phosphorylation levels of IRS-1 and PI3K/Akt signaling molecules involved in GSIS were investigated in 3DG-treated cells co-incubated with high glucose $(25.5 \mathrm{mM})$ for $12 \mathrm{~h}$. As presented in Fig. 4A and B, 3DG treatment with INS-1 cells led to a significant reduction of IRS-1, PI3K-p85 and Akt phosphorylation in a dose dependent manner. These results suggested that 3DG treatment impaired insulin secretion, at least in part, through interfering with insulin-PI3K signaling. The idea was further supported by the fact that 3DG treatment decreased the expression of GLUT2 (Fig. 4C).

\section{Discussion}

The objective of the present study was to investigate the effects of continuous intragastric administration of a dietary composition, 3DG, on fasting blood glucose levels, oral glucose tolerance, plasma 3DG levels and $\beta$-cell function in normal mice. The study has confirmed that normal mice developed impaired glucose tolerance in conjunction with slightly increased fasting blood glucose concentrations, associated with the impaired $\beta$-cell function. This occurred together with an obvious increase in plasma 3DG levels following administration of $3 \mathrm{DG}$ that further support for the impaired $\beta$-cell function.

Impaired glucose regulation (IGR) has been recognized as a high risk state for type 2 diabetes mellitus (T2DM). The rapid conversion of pre-diabetes to T2DM (annualized conversion rate in the range of $5-10 \%$ ) and the increasing prevalence of pre-diabetes ( $>470$ million people projected to live with pre-diabetes worldwide by 2030) resulting in an ever-increasing prevalence of T2DM (34). A significance of dietary factors on understanding of the epidemic has been well recognized. The increased intake of dietary carbohydrate or fat has been clearly demonstrated to be important to development of pre-diabetes (35). Aside from the known nutrient composition, other dietary factors seem to serve an essential part. This 

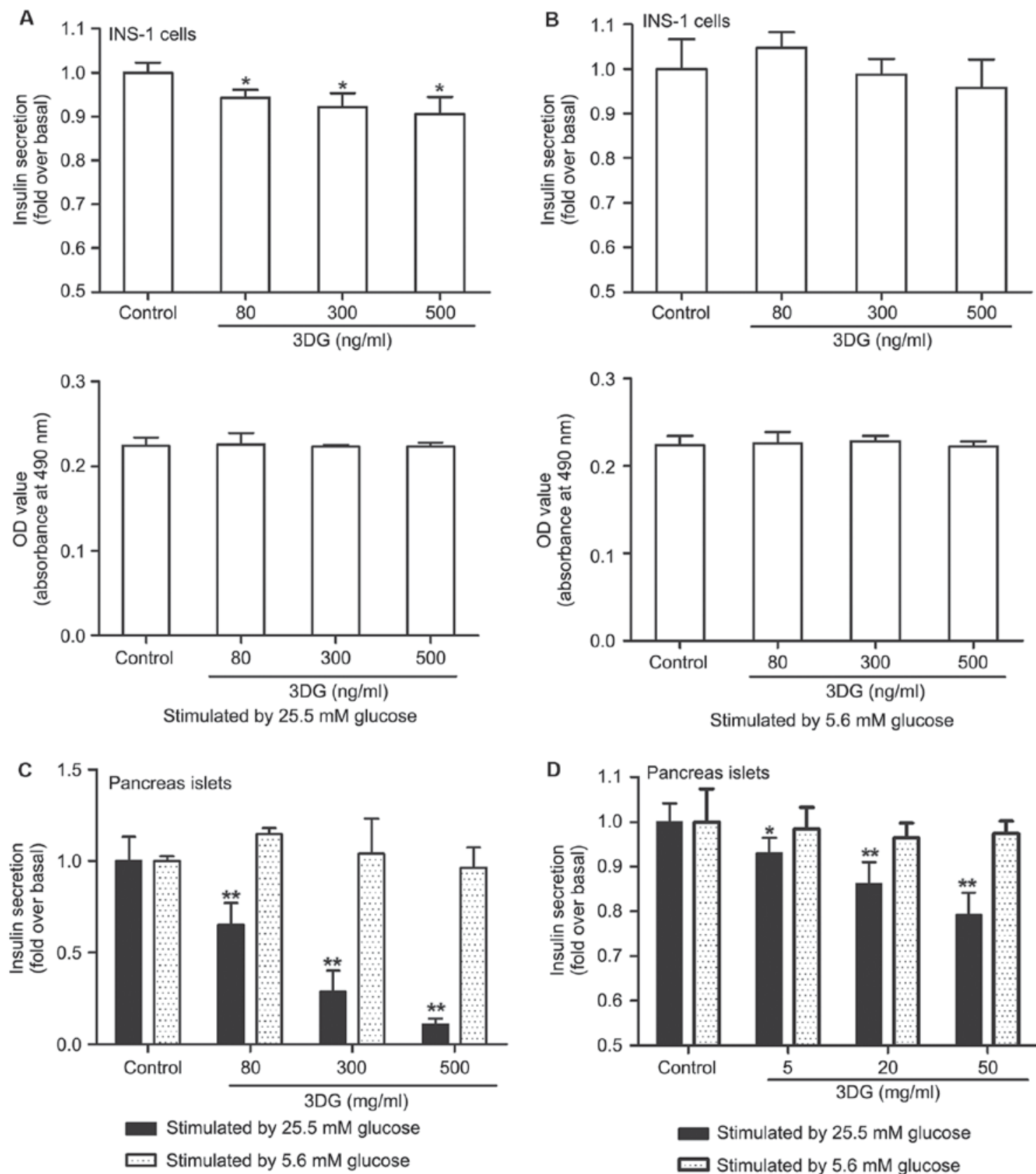

Figure 3. Effect of 3DG treatment on GSIS in cultured inlets and INS-1 cells. GSIS was measured following INS-1 cell treatment with 3DG (80, 300 and $500 \mathrm{ng} / \mathrm{ml})$ in response to the (A) high glucose $(25.5 \mathrm{mM})$ and the (B) low glucose $(5.6 \mathrm{mM})$ for $12 \mathrm{~h}$ with the MTT assay corrects error. (C) GSIS was measured in pancreas islets from the normal rats treatment with 3DG $(80,300$ and $500 \mathrm{ng} / \mathrm{ml})$ in response to the high glucose and the low glucose for $12 \mathrm{~h}$. (D) GSIS was measured in cultured pancreas islets from the acute intravenous injection of 3DG-treated rats $(5,20 \mathrm{and} 50 \mathrm{mg} / \mathrm{kg})$ in response to the high glucose and the low glucose for $12 \mathrm{~h}$. Values are presented as the mean \pm standard deviation. ${ }^{*} \mathrm{P}<0.05,{ }^{* *} \mathrm{P}<0.01 \mathrm{vs}$. control (n=6). 3DG, 3-deoxyglucosone; GSIS, glucose-stimulated insulin secretion.

result clearly indicates that $3 \mathrm{DG}$, the predominant 1,2 -dicarbonyl compound in foods, was administrated to normal mice by gastric gavage for two weeks to induce the development of IGR (Fig. 1). IGR may be due to decreased $\beta$-cell function and/or an impairment in insulin action on peripheral tissues. Several studies have documented that decreased $\beta$-cell function is already present in the IGR and gradually recognized to be the primary cause of $\operatorname{IGR}(2,36,37)$. Furthermore, at concentrations similar to those obtained from plasma contents in 3DG-treated mice, 3DG directly decreased GSIS in a dose-dependent manner in cultured pancreas islets and INS-1 cells under high glucose conditions (Fig. 3A and C), which further provide a possible explanation for the observed $\beta$-cell dysfunction in 3DG-treated mice. In addition, a rise in the fasting glucose concentrations within the normal range was observed in 3DG-treated mice (Fig. 1B), is suggested to be due to a continuous fall in $\beta$-cell function (38). A previous report documented that the acute elevated plasma 3DG through the intravenous injection impaired $\beta$-cell function (29). In the present study, increased plasma 3DG levels in 3DG-treated mice were observed (Fig. 1A). These results not only further support the role of $\beta$-cell dysfunction in IGR, but suggested that abnormal elevation of circulating 3DG participates in inducing a decreased $\beta$-cell function. 
A

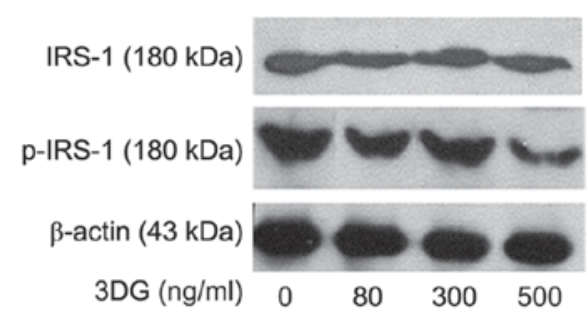

B

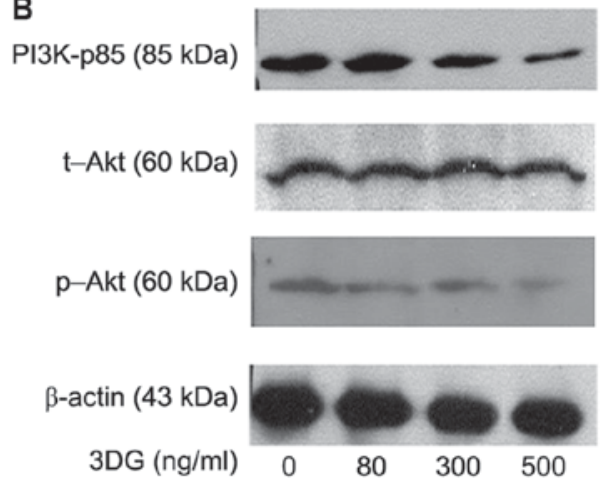

C

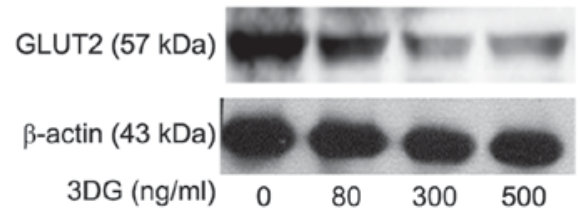

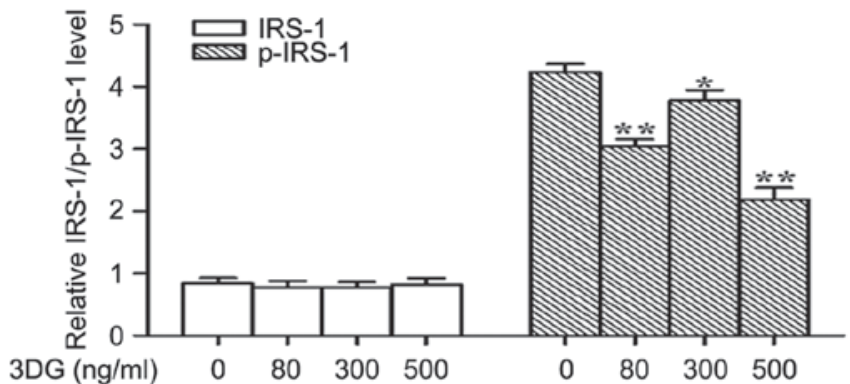
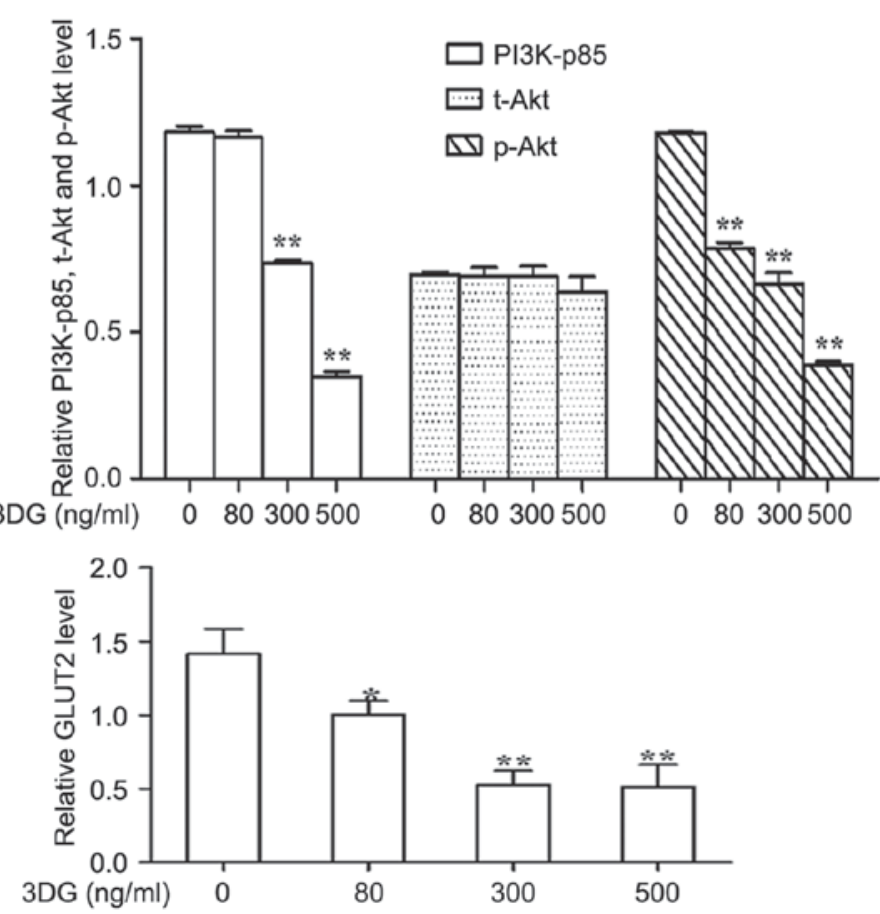

Figure 4. Effects of 3DG treatment on insulin signaling in INS-1 cells. INS-1 cells were incubated for $12 \mathrm{~h}$ without or with 3DG (80,300 and 500 ng/ml) in RPMI1640 containing $25.5 \mathrm{mM}$ glucose. Western blotting presented the expression levels of (A) p-IRS-1, (B) PI3K-p85, p-AKT and (C) GLUT2 in INS-1 cells . Values are presented as the mean \pm standard deviation. ${ }^{*} \mathrm{P}<0.05,{ }^{* * *} \mathrm{P}<0.01$ vs. $0 \mathrm{ng} / \mathrm{ml}$ 3DG ( $\mathrm{n}=6$ ). 3DG, 3-deoxyglucosone; PI3K, phosphoinositide 3-kinase; AKT, protein kinase B; GLUT2, glucose transporter 2.

The function of $\beta$-cells depends on glucose uptake and the subsequent signaling pathways that influence insulin secretion. The uptake of glucose in pancreatic $\beta$-cells is primarily mediated by GLUT2 that permits rapid glucose uptake regardless of the extracellular sugar concentration, and is identified in high levels in $\beta$-cells (39). Previous reports have documented that GLUT2 is one of key mechanisms in control of glucose-dependent insulin secretion $(40,41)$. In the present study, treatment with 3DG decreased the expression of GLUT2 in high glucose-induced INS-1 cells (Fig. 4), which partly accounts for the decreased GSIS. This occurs together with a significant reduction in the phosphorylation levels of IRS-1, p85-PI3K and Akt, which further confirmed the effect of 3DG on GLUT2 expression (Fig. 4). The finding in INS-1 cells is consistent with those obtained in hepatocellular carcinoma cells HepG2, in which 3DG impairs insulin signaling (30). In addition to regulating GLUT2 (42), pancreatic and duodenal homeobox factor-1 (PDX-1) is also a key downstream molecule of the insulin-PI3K signal pathway (43). It has been reported that decreased PDX-1 expression results in a reduction in insulin mRNA expression and impairment of glucose stimulated insulin secretion (44). Additionally, the
insulin-PI3K signal pathway participates in modulating intracellular $\mathrm{Ca}^{2+}$ flux that directly affects the rate of exocytosis of insulin (10). Therefore, 3DG decreased $\beta$-cell function, at least in part, through interfering with the insulin-PI3K signaling pathway. On the basis of these results, it is not known how 3DG impairs insulin signaling, but we can just speculate about the mechanistic insight. 1) 3DG was reported to cause the direct chemical modification of lysine and arginine residues in proteins by binding (45), which may lead to a decrease in the expression of the corresponding proteins. 2) A number of observations indicate that dicarbonyl compounds, including 3DG and MGO, impair intracellular signaling via the production of reactive oxygen species (20). 3) The ability of 3DG to impair insulin signaling may be indirectly mediated by producing advanced glycation end products.

Although a single oral administration study has indicated that the absorption rate of 3DG from foodstuffs is very slow (33), it is unknown whether continuous oral administration of 3DG causes an increased plasma 3DG levels in normal individuals. In presented experiments, the level of plasma 3DG was elevated two-fold in the range of 76-119 $\mathrm{ng} / \mathrm{ml}$ following 2-week administration of 3DG in mice that were already at 
the pre-diabetic stage. The elevated 3DG levels in plasma are primarily attributed to the intake of exogenous 3DG. The current study suggested a potential action pathway linking exogenous 3DG and development of pre-diabetes though an increase in the plasma 3DG levels.

In summary, it is the first demonstration that exogenous 3DG at two weeks following intragastric administration led normal mice to develop IGR resulting from $\beta$-cell dysfunction. In addition, the present study demonstrated that increased plasma 3DG levels in the 3DG-treated mice participates in inducing $\beta$-cell dysfunction, at least in part, through impairing with insulin-PI3K signaling, which provides the link between exogenous 3DG and the development of IGR. The study suggests a pathogenic mechanism linking between dietary and $\beta$-cell dysfunction with the cumulative toxicity of 3DG given daily, thus 3DG may be a novel target for protection of $\beta$-cell function and treatment and prevention of IGR.

\section{Acknowledgments}

The present work was supported by the research funds from Suzhou Science and Technology Department (grant nos. SYS201423, and SYSD2015122), and the research fund from the Suzhou Youth Science and Education Project (grant no. KJXW2014027).

\section{References}

1. Giuseppe D, Muhammad AG and Defronzo RA: What are the pharmacotherapy options for treating prediabetes? Expert Opin Pharmaco 15: 2003-2018, 2014.

2. Abdul-Ghani MA, Tripathy D and DeFronzo RA: Contributions of beta-cell dysfunction and insulin resistance to the pathogenesis of impaired glucose tolerance and impaired fasting glucose. Diabetes Care 29: 1130-1139, 2006.

3. Rhodes CJ, White MF, Leahy JL and Kahn SE: Direct autocrine action of insulin on $\beta$-cells: Does it make physiological sense? Diabetes 62: 2157-2163, 2013.

4. Leibiger IB, Leibiger B and Berggren PO: Insulin signaling in the pancreatic beta-cell. Annu Rev Nutr 28: 233-251, 2008.

5. Kulkarni RN, Brüning JC, Winnay JN, Postic C, Magnuson MA and Kahn CR: Tissue-specific knockout of the insulin receptor in pancreatic beta cells creates an insulin secretory defect similar to that in type 2 diabetes. Cell 96: 329-339, 1999.

6. Kulkarni RN: Receptors for insulin and insulin-like growth factor-1 and insulin receptor substrate-1 mediate pathways that regulate islet function. Biochem Soc Trans 30: 317-322, 2002.

7. Kulkarni RN, Winnay JN, Daniels M, Brüning JC, Flier SN, Hanahan D and Kahn CR: Altered function of insulin receptor substrate-1-deficient mouse islets and cultured beta-cell lines. J Clin Invest 104: R69-R75, 1999.

8. Withers DJ, Gutierrez JS, Towery H, Burks DJ, Ren JM, Previs S, Zhang Y, Bernal D, Pons S, Shulman GI, et al: Disruption of IRS-2 causes type 2 diabetes in mice. Nature 391: 900-904, 1998.

9. Rothenberg PL, Willison LD, Simon J and Wolf BA: Glucose-induced insulin receptor tyrosine phosphorylation in insulin-secreting beta-cells. Diabetes 44: 802-809, 1995.

10. Aspinwall CA, Qian WJ, Roper MG, Kulkarni RN, Kahn CR and Kennedy RT: Roles of insulin receptor substrate-1, phosphatidylinositol 3-kinase, and release of intracellular $\mathrm{Ca}^{2+}$ stores in insulin-stimulated insulin secretion in beta -cells. J Biol Chem 275: 22331-22338, 2000.

11. da Silva Xavier G, Varadi A, Ainscow EK and Rutter GA: Regulation of gene expression by glucose in pancreatic beta -cells (MIN6) via insulin secretion and activation of phosphatidylinositol 3'-kinase. J Biol Chem 275: 36269-36277, 2000.

12. Maessen DE, Hanssen NM, Scheijen JL, van der Kallen CJ, van Greevenbroek MM, Stehouwer CD and Schalkwijk CG: Post-glucose load plasma $\alpha$-dicarbonyl concentrations are increased in individuals with impaired glucose metabolism and type 2 diabetes: The CODAM study. Diabetes Care 38: 913-920, 2015.
13. Dhar A, Desai KM and Wu L: Alagebrium attenuates acute methylglyoxal-induced glucose intolerance in Sprague-Dawley rats. Br J Pharmacol 159: 166-175, 2010.

14. Riboulet-Chavey A, Pierron A, Durand I, Murdaca J, Giudicelli J and Van Obberghen E: Methylglyoxal impairs the insulin signaling pathways independently of the formation of intracellular reactive oxygen species. Diabetes 55: 1289-1299, 2006.

15. Jia $X$ and Wu L: Accumulation of endogenous methylglyoxal impaired insulin signaling in adipose tissue of fructose-fed rats. Mol Cell Biochem 306: 133-139, 2007.

16. Fiory F, Lombardi A, Miele C, Giudicelli J, Beguinot F and Van Obberghen E: Methylglyoxal impairs insulin signalling and insulin action on glucose-induced insulin secretion in the pancreatic beta cell line INS-1E. Diabetologia 54: 2941-2952, 2011.

17. Eriksson UJ, Wentzel P, Minhas HS and Thornalley PJ: Teratogenicity of 3-deoxyglucosone and diabetic embryopathy. Diabetes 47: 1960-1966, 1998.

18. Degen J, Hellwig M and Henle T: 1,2-dicarbonyl compounds in commonly consumed foods. J Agric Food Chem 60: 7071-7079, 2012.

19. Okado A, Kawasaki Y, Hasuike Y, Takahashi M, Teshima T, Fujii J and Taniguchi N: Induction of apoptotic cell death by methylglyoxal and 3-deoxyglucosone in macrophage-derived cell lines. Biochem Biophys Res Commun 225: 219-224, 1996.

20. Che W, Asahi M, Takahashi M, Kaneto H, Okado A, Higashiyama $S$ and Taniguchi N: Selective induction of heparin-binding epidermal growth factor-like growth factor by methylglyoxal and 3-deoxyglucosone in rat aortic smooth muscle cells. The involvement of reactive oxygen species formation and a possible implication for atherogenesis in diabetes. J Biol Chem 272: 18453-18459, 1997.

21. Kalapos MP: Methylglyoxal in living organisms: Chemistry, biochemistry, toxicology and biological implications. Toxicol Lett 110: 145-175, 1999.

22. Niwa T: 3-Deoxyglucosone: Metabolism, analysis, biological activity, and clinical implication. J Chromatogr B Biomed Sci Appl 731: 23-36, 1999.

23. Sassi-Gaha S, Loughlin DT, Kappler F, Schwartz ML, Su B, Tobia AM and Artlett CM: Two dicarbonyl compounds, 3-deoxyglucosone and methylglyoxal, differentially modulate dermal fibroblasts. Matrix Biol 29: 127-134, 2010.

24. Wang Q, Jiang GR and Zhang LR: Effects of 3-deoxyglucosone on blood glucose of normal mice. Chinese J Diabetes 18: 220-222, 2010.

25. Lal S, Kappler F, Walker M, Orchard TJ, Beisswenger PJ, Szwergold BS and Brown TR: Quantitation of 3-deoxyglucosone levels in human plasma. Arch Biochem Biophys 342: 254-260, 1997.

26. Hamada Y, Nakamura J, Fujisawa H, Yago H, Nakashima E, Koh N and Hotta N: Effects of glycemic control on plasma 3-deoxyglucosone levels in NIDDM patients. Diabetes Care 20: 1466-1469, 1997.

27. Beisswenger PJ, Howell SK, O'Dell RM, Wood ME, Touchette AD and Szwergold BS: alpha-Dicarbonyls increase in the postprandial period and reflect the degree of hyperglycemia. Diabetes Care 24: 726-732, 2001.

28. Jiang G, Zhang L, Ji Q, Wang F, Xu H, Huang F and Wang C: Accumulation of plasma 3-deoxyglucosone impaired glucose regulation in Chinese seniors: Implication for senile diabetes? Diabetes Metab Syndr 6: 140-145, 2012.

29. Liang G, Song X, Xu H, Wang F, Zhang L, Zhou L and Jiang G: 3-Deoxyglucosone induced acute glucose intolerance in sprague-dawley rats: Involvement of insulin resistance and impaired $\beta$-cell function. Exp Clin Endocrinol Diabetes 124: 431-436, 2016.

30. Liang G, Wang F, Song X, Zhang L, Qian Z and Jiang G: 3-Deoxyglucosone induces insulin resistance by impairing insulin signaling in HepG2 cells. Mol Med Rep 13: 4506-4512, 2016.

31. Kahn SE, Cooper ME and Del Prato S: Pathophysiology and treatment of type 2 diabetes: Perspectives on the past, present, and future. Lancet 383: 1068-1083, 2014.

32. Schwartz MW, Seeley RJ, Tschöp MH, Woods SC, Morton GJ, Myers MG and D'Alessio D: Cooperation between brain and islet in glucose homeostasis and diabetes. Nature 503: 59-66, 2013.

33. Kato H, van Chuyen N, Shinoda T, Sekiya F and Hayase F: Metabolism of 3-deoxyglucosone, an intermediate compound in the Maillard reaction, administered orally or intravenously to rats. Biochim Biophys Acta 1035: 71-76, 1990. 
34. Tabák AG, Herder C, Rathmann W, Brunner EJ and Kivimäki M Prediabetes: A high-risk state for diabetes development. Lancet 379: 2279-2290, 2012.

35. Hu FB, Van Dam RM and Liu S: Diet and risk of type II diabetes: The role of types of fat and carbohydrate. Diabetologia 44 805-817, 2001.

36. Tabák AG, Jokela M, Akbaraly TN, Brunner EJ, Kivimäki M and Witte DR: Trajectories of glycaemia, insulin sensitivity, and insulin secretion before diagnosis of type 2 diabetes: An analysis from the Whitehall II study. Lancet 373: 2215-2221, 2009.

37. Gastaldelli A, Ferrannini E, Miyazaki Y, Matsuda M and DeFronzo RA; San Antonio metabolism study: Beta-cell dysfunction and glucose intolerance: Results from the San Antonio metabolism (SAM) study. Diabetologia 47: 31-39, 2004.

38. Stancáková A, Javorský M, Kuulasmaa T, Haffner SM, Kuusisto J and Laakso M: Changes in insulin sensitivity and insulin release in relation to glycemia and glucose tolerance in 6,414 Finnish men. Diabetes 58: 1212-1221, 2009.

39. Thorens B, Sarkar HK, Kaback HR and Lodish HF: Cloning and functional expression in bacteria of a novel glucose transporter present in liver, intestine, kidney, and beta-pancreatic islet cells. Cell 55: 281-290, 1988.
40. Unger RH: Diabetic hyperglycemia: Link to impaired glucose transport in pancreatic beta cells. Science 251: 1200-1205, 1991.

41. Guillam MT, Hümmler E, Schaerer E, Yeh JI, Birnbaum MJ, Beermann F, Schmidt A, Dériaz N and Thorens B: Early diabetes and abnormal postnatal pancreatic islet development in mice lacking Glut-2. Nat Genet 17: 327-330, 1997.

42. Assmann A, Ueki K, Winnay JN, Kadowaki T and Kulkarni RN: Glucose effects on beta-cell growth and survival require activation of insulin receptors and insulin receptor substrate 2. Mol Cell Biol 29: 3219-3228, 2009.

43. Kaneto H, Matsuoka TA, Miyatsuka T, Kawamori D, Katakami N, Yamasaki Y and Matsuhisa M: PDX-1 functions as a master factor in the pancreas. Front Biosci 13: 6406-6420, 2008.

44. Brissova M, Shiota M, Nicholson WE, Gannon M, Knobel SM, Piston DW, Wright CV and Powers AC: Reduction in pancreatic transcription factor PDX-1 impairs glucose-stimulated insulin secretion. J Biol Chem 13: 11225-11232, 2002.

45. Sakiyama H, Takahashi M, Yamamoto T, Teshima T, Lee SH, Miyamoto Y, Misonou Y and Taniguchi N: The internalization and metabolism of 3-deoxyglucosone in human umbilical vein endothelial cells. J Biochem 139: 245-253, 2006. 